\title{
Association between the HTR2C rs1414334 C/G gene polymorphism and the development of the metabolic syndrome in patients treated with atypical antipsychotics.
}

José M Rico-Gomis, Antonio Palazón-Bru, Irene Triano-García, Luis F Mahecha-García, Ana García-Monsalve, Andrés Navarro-Ruiz, Berta Villagordo-Peñalver, Jessica Jiménez-Abril, Alicia Martínez-Hortelano, Vicente F Gil-Guillén

Few studies have assessed the association between the rs1414334 C/G polymorphism in the HTR2C gene and the development of the metabolic syndrome in patients treated with atypical antipsychotics. To provide further evidence, a cross-sectional study was conducted in Spain between 2012 and 2013 in 166 patients with these characteristics. In these patients, the association between the polymorphism and the presence of the metabolic syndrome was determined by implementing binary logistic regression models adjusted for variables associated with the metabolic syndrome. We did not confirm previous claims that the $\mathrm{C}$ allele of the polymorphism was linked to the metabolic syndrome: the association was in the opposite direction and non-significant. This conclusion held after taking gender and lifestyle variables into account. 


\section{AUTHOR COVER PAGE:}

2 Title: Association between the HTR2C rs $1414334 \mathrm{C} / \mathrm{G}$ gene polymorphism and the development

3 of the metabolic syndrome in patients treated with atypical antipsychotics.

4

5 Authors: José María Rico-Gomis [1,2], Antonio Palazón-Bru [2,3], Irene Triano-García [4], Luis

6 Fabián Mahecha-García [1], Ana García-Monsalve [4], Andrés Navarro-Navarro [4], Berta

7 Villagordo-Peñalver [1], Jessica Jiménez-Abril [1], Alicia Martínez-Hortelano [1], Vicente

8 Francisco Gil-Guillén [2,3].

10 Institutions:

11 1) Department of Psychiatry, General University Hospital of Elche, Elche, Alicante, Spain.

12 2) Department of Clinical Medicine, Miguel Hernández University, San Juan de Alicante,

13 Alicante, Spain.

14 3) Research Unit, General University Hospital of Elda, Elda, Alicante, Spain.

15 4) Pharmacy Service, General University Hospital of Elche, Elche, Alicante, Spain.

17 Corresponding author: Prof. Antonio Palazón-Bru, PhD. Department of Clinical Medicine,

18 Miguel Hernández University, Carretera de Valencia - Alicante S/N, 03550, San Juan de

19 Alicante (Spain). Phone number: +34 965919449. Fax number: +34 965919450. E-mail:

20 antonio.pb23@gmail.com 


\section{ABSTRACT:}

23 Few studies have assessed the association between the $\mathrm{rs} 1414334 \mathrm{C} / \mathrm{G}$ polymorphism in the

24 HTR2C gene and the development of the metabolic syndrome in patients treated with atypical

25 antipsychotics. To provide further evidence, a cross-sectional study was conducted in Spain

26 between 2012 and 2013 in 166 patients with these characteristics. In these patients, the

27 association between the polymorphism and the presence of the metabolic syndrome was

28 determined by implementing binary logistic regression models adjusted for variables associated

29 with the metabolic syndrome. We did not confirm previous claims that the $\mathrm{C}$ allele of the

30 polymorphism was linked to the metabolic syndrome: the association was in the opposite

31 direction and non-significant. This conclusion held after taking gender and lifestyle variables

32 into account. 


\section{INTRODUCTION}

Cardiovascular disease is the leading cause of mortality in the world (WHO, 2014). Its main risk factors are hypertension, diabetes mellitus and dyslipidemia, which are grouped together in the definition of the metabolic syndrome (Alberti et al., 2005; Grundy et al., 2004). This syndrome occurs more frequently in schizophrenic patients (McEvoy et al., 2005; Meyer \& Stahl, 2009), leading to an increase in cardiovascular risk (Osby et al., 2000; Casey et al., 2004).

In this type of patient, taking atypical antipsychotics can cause an increase in the probability of having the metabolic syndrome (Newcomer, 2004; McEvoy et al., 2005). The weight gain associated with the metabolic syndrome is related to both environmental and genetic factors (Gebhardt et al., 2010). Therefore identifying relevant genetic variants would be useful when choosing personalized treatments, minimizing the risk of cardiovascular disease in those patients genetically predisposed to developing the metabolic syndrome.

Among the genes involved, previous studies have reported an association between specific polymorphisms in the HTR2C gene and development of the metabolic syndrome in these patients (Mulder et al., 2007; Mulder et al., 2009; Risselada et al., 2012; Ma et al., 2014). 5HT2C agonists decrease appetite (Clifton, Lee \& Dourish, 2000), while antagonists increase appetite (Bonhaus et al., 1997). In addition, it appears that 5-HT2C receptors are related to the anorexigenic effects of leptin (von Meyenburg, Langhans \& Hrupka, 2003; Reynolds et al., 2006).

54 For this reason multiple genetic variants of the HTR2C gene have been studied. Various polymorphisms such as $-759 \mathrm{C},-697 \mathrm{C} / \mathrm{G},-997 \mathrm{G} / \mathrm{A},-1165 \mathrm{~A} / \mathrm{G}$ have been evaluated, finding associations with the development of the metabolic syndrome. At times these associations have 
57 shown conflicting results (Wallace et al., 2011). Our focus was on the rs $1414334 \mathrm{C} / \mathrm{G}$

58 polymorphism in the HTR2C gene, because in our literature search we found only 3 studies, conducted in the Netherlands, of which two were replication studies (Mulder et al., 2007; Mulder et al., 2009; Risselada et al., 2012). In the first study (Mulder et al., 2007), among patients receiving treatment with atypical antipsychotics, 10 out of $21(48 \%)$ with the $\mathrm{C}$ allele had the metabolic syndrome compared with 18 out of $91(20 \%)$ with the G allele. In the first replication study (Mulder et al., 2009), 13 in 31 patients with the $\mathrm{C}$ allele had the metabolic syndrome (42\%), and 39 in 133 patients with the G allele had the syndrome (29\%). Finally, in the second replication study (Risselada et al., 2012), 16 out of 30 patients with the $\mathrm{C}$ allele had the metabolic syndrome (53\%), compared with 40 out of $132(30 \%)$ with the G allele. Later, a metaanalysis included these three studies and determined a significant association between the presence of the $\mathrm{C}$ allele of the rs 1414334 polymorphism and the prevalence of the metabolic syndrome in patients receiving treatment with atypical antipsychotics (Ma et al., 2014). On the other hand, HTR2C is X-linked, and so females can be heterozygous whereas males have only one copy of the gene. Data from these previous studies did not, however, break down results by gender studies (Mulder et al., 2007; Mulder et al., 2009; Risselada et al., 2012).

This behavior has also been noted in the 759C/T and 997G/A polymorphisms in the HTR2C gene, where some authors have found these polymorphisms to have a protective nature against the metabolic syndrome, whilst others have found them to be of risk and the remainder found no difference (Wallace et al., 2011; Ma et al., 2014). Additionally, these authors found that other polymorphisms of the 5-HT2C gene (not rs 1414334) were associated with weight gain in earlier stages of treatment (Wallace et al., 2011). In other words, in the scientific literature contradictory or null results in different polymorphisms of the HTR2C gene are reported (Ma et al., 2014). 
80 Since in the rs 1414334 polymorphism the results were consistent, but were always analyzed by

81 the same research group in the same region (Mulder et al., 2007; Mulder et al., 2009; Risselada

82 et al., 2012), we decided to ascertain whether their results agreed with those obtained in other

83 geographical areas, such as Spain. For this reason, to provide further evidence for the possible

84 association between this polymorphism and the metabolic syndrome in psychotic patients, we

85 conducted a study in Spain. We aimed to replicate the previous finding of an association between

86 the presence of the $\mathrm{C}$ allele of rs1414334 and the metabolic syndrome in patients treated with

87 atypical antipsychotics. We extended previous work by considering gender effects on the

88 association, and by incorporating measures of relevant lifestyle variables, such as diet.

MATERIALS \& METHODS

91

92

93

94

95

96

97

98

99

100

\section{Setting}

The proposed study was conducted in the Elche, Crevillente and Santa Pola Department of Health of the Valencian Community, which is a Mediterranean region located in southeastern Spain. In its mental health services, coverage is provided to approximately 325,000 inhabitants (almost entirely Caucasian). Health care is universal and free for all patients, except those with an irregular immigration status.

\section{Study design and participants}

In this cross-sectional, observational study, a sample of inpatients and outpatients treated for at least three months with atypical antipsychotics (clozapine, olanzapine, risperidone, quetiapine, aripiprazole, ziprasidone, amisulpride, asenapine and paliperidone) was analyzed. For the 
101 sample, consecutive patients attending Mental Health Services of the Valencian Community at

102 the Elche, Crevillente and Santa Pola Department of Health between December 2012 and June

1032013 were selected. All patients had to be of legal age ( $>18$ years) and have a diagnosis of a

104 psychotic disorder. This was defined as having a psychiatrist's diagnosis of schizophrenia,

105 schizophreniform disorder, schizoaffective disorder or other psychotic disorders, or bipolar

106 disorder, and continuous treatment with antipsychotic medication (American Psychiatric

107 Association, 2000). To comply with the current legislation, all patients were adequately informed

108 about the study (written form) and, if agreeing to participate, signed a consent form before

109 inclusion.

110 The study was approved by the Clinical Research Ethics Committee of the General University

111 Hospital of Elche on November 20, 2012.

\section{Variables and measurements}

113 The primary variable was the diagnosis of the metabolic syndrome using the ATPIII criteria

114 (Grundy et al., 2004), i.e., the presence of three or more of the following metabolic criteria:

115 abdominal obesity, hypertriglyceridemia, low levels of high density lipoprotein cholesterol

116 (HDL-C), elevated blood pressure and insulin resistance. All parameters of the metabolic

117 syndrome criteria were determined using appropriate clinical guidelines (No authors listed, 1998;

118 NCEP, 2002; Mancia et al., 2007; American Diabetes Association, 2012).

119 Secondary clinical variables were: age (years), gender, diagnosis (schizophrenia or other)

120 (American Psychiatric Association, 2000), years with the diagnosis, treatment duration with the

121 current antipsychotic (years), continuing therapy with a favorable (aripiprazole, ziprasidone or

122 palperidone) or unfavorable (olanzapine, clozapine, risperidone, quetiapine or asenapine) 
123 (American Diabetes Association et al., 2004; Stahl et al., 2009; Schreiner et al., 2012; Stoner \&

124 Pace, 2012; Fleischhacker et al., 2013; Young et al., 2015) metabolic profile, use of

125 antidepressants, mood stabilizers and number of pack-years (number of cigarettes smoked per

126 day $\times$ number of years smoked)/20). These variables were obtained by clinical interview with the

127 patient and corroborated by the electronic medical record. It is obligatory that all drug

128 prescriptions be made through this computerized system (Agencia Valenciana de Salud, 2011).

129 The following variables related to lifestyle were obtained by conducting the National Survey of

130 Health and the European Health Survey (Ministerio de Sanidad, Política Social e Igualdad \&

131 Instituto Nacional de Estadística, 2009; Ministerio de Sanidad, Servicios Sociales e Igualdad \&

132 Instituto Nacional de Estadística, 2011): usual number of hours of sleep, physical activity during

133 leisure time and habitual activity (work and home) and consumption of food (fruit, meat, eggs,

134 fish, pasta, rice and potatoes, bread and cereals, vegetables, legumes, cold meats, milk products

135 and sweets). Regular physical activity was assessed on a scale as follows: 0, sitting; 1 standing; 2

136 walking or moving around; 3 great effort. Physical activity during leisure time was measured

137 with the following scale: 0 , never; 1 , less than once per month; 2 , once or several times per

138 month; 3, one or more times per week. Finally, the scale of all the food (fruit, meat, eggs, fish,

139 pasta, rice and potatoes, bread and cereals, vegetables, legumes, cold meats, milk products and

140 sweets) was rated as: 0 , daily; 1 , three or more times per week; 2, once or twice per week; 3, less

141 than once per week; 4 never or almost never.

142 DNA isolation and genotyping

143 Genomic DNA was extracted from EDTA blood samples using the semi-automated QIAcube 144 system (Qiagen, Hilden, Germany). The rs1414334 C/G polymorphism was analyzed by real- 
145 time PCR using a pre-developed assay (C_7455701_10, Applied Biosystems, Madrid, Spain) for

146 allelic discrimination in a 7300 Real-Time PCR System (Applied Biosystems). The reaction was

147 carried out with a TaqMan genotyping PCR master mix (Applied Biosystems), according to the

148 protocol provided by Applied Biosystems.

149 The rs 1414334 polymorphism allele $\mathrm{C} / \mathrm{G}$ is described in the SNP database

150 (http://www.ncbi.nkm.nih.gov/snp)

151 Sample size

152 The sample size during the study period was 166 patients, 68 of whom had the metabolic

153 syndrome. As the sample was collected a posteriori, the power of the test was calculated to

154 establish an association between an exposure factor and a disease, that is, whether an odds ratio

155 (OR) is different from 1. For this calculation we assumed $\mathrm{C}$ allele in $30 \%$ of cases and $13 \%$ of

156 controls, a control/case ratio of 2:1 and a type I error of 5\% (Risselada et al., 2012). With these

157 parameters the power of the test was $81.7 \%$.

\section{Statistical methods}

159 All variables were described using frequencies (absolute and relative), means and standard

160 deviations. A stepwise logistic regression model was constructed to determine the relationship

161 between the polymorphism and the metabolic syndrome. Since we had 68 events (metabolic

162 syndrome), the model could only hold a maximum of 6 explanatory variables (one for every 10

163 events) (Ramírez-Prado et al., 2015). As we had a total of 25 variables, to determine which

164 would be introduced in the model we first compared proportions and means between the

165 metabolic syndrome (yes and no) by using the Chi-square test and the t-test, and then selected 
166 those variables with the smaller p-value. Thus the adjusted OR were obtained. The goodness-of-

167 fit of the final model was assessed using the likelihood ratio test.

168 Since the HTR2C gene is X-linked, all the analyses were carried out for men and women

169 separately. This is important because women encounter a very different situation than men.

170 Women can be heterozygote, whereas men cannot, which creates a completely different

171 biological scenario. This is also important with respect to previous articles published on this

172 topic (Mulder et al., 2007; Mulder et al., 2009; Risselada et al., 2012).

173 All analyses were performed with a significance of 5\% and for each relevant parameter its 174 associated confidence interval (CI) was calculated. The statistical package used was IBM SPSS 175 Statistics 19 (IBM, Armonk, NY, USA).

177 RESULTS

178 In the patients with the rs1414334 $\mathrm{C}$ allele, the prevalence of the metabolic syndrome was: total, $17930.3 \%$; men, 35.7\%; and women, $26.3 \%$. These values for the rs $1414334 \mathrm{C}$ allele were: total, $18043.6 \%$; men, 47.1\%; and women, 37.5\%. There were no differences between the polymorphism 181 and our outcome $(0.164<$ p-value $<0.430)$ (Tables $1-3)$.

182 The descriptive and analytical characteristics of the total sample are shown in Table 1 . We emphasize the prevalence of the $\mathrm{C}$ allele of the polymorphism of $19.9 \%$ and of the diagnosis of

184 schizophrenia (55.4\%), a high proportion of drugs with an unfavorable metabolic profile $(82.5 \%)$ 185 and an average disease duration close to 15 years. Regarding the differences in the diagnosis of 186 the metabolic syndrome (Table 1), we found statistically significant differences in the following 
187 variables $(p<0.05)$ : older age $(p=0.038)$ and antidepressants $(p=0.044)$. The rs $1414334 \mathrm{C}$ allele

188 did not show any difference $(\mathrm{p}=0.164)$. When we analyzed the factors associated with the

189 metabolic syndrome (Table 1), no variables were significantly different, including the $\mathrm{C}$ allele of

190 the polymorphism ( $\mathrm{p}=0.062)$ (direction contrary to prediction).

191

192

193

In the men (Table 2), we noted differences between an older age and the prevalence of the metabolic syndrome $(\mathrm{p}=0.011)$. On the other hand, the logistic regression model only showed one significant factor associated with the metabolic syndrome (older age), and the $\mathrm{C}$ allele of the polymorphism had the same association as was found in the total sample (inverse and nonsignificant, $p=0.141$ ). Finally (Table 3 ), in the women there were no differences in the bivariate analysis (Chi-square test and the t-test), no significant factors associated with our outcome, and the studied polymorphism had the same result as in the total sample and in the men (inverse and non-significant, $\mathrm{p}=0.318$ ).

\section{DISCUSSION}

Summary

204

This study found no statistically significant association between the presence of the C allele of

205 the rs1414334 polymorphism in the HTR2C gene and the metabolic syndrome. 
207 The main strength of this study is that it provides greater knowledge of the association between

208 the polymorphism analyzed and the metabolic syndrome. Moreover, all the variables that the

209 Dutch group did not analyze in their studies were taken into account, such as physical activity,

210 diet and smoking (Mulder et al., 2007; Mulder et al., 2009; Risselada et al., 2012). To minimize

211 information bias, all measurements were taken in direct contact with the patient and according to

212 current clinical guidelines. To minimize selection bias, data were taken from all the patients who

213 attended mental health services during a specific period (6 months).

214 Regarding limitations, we must bear in mind that our design is cross-sectional, thus we could not 215 establish causal relationships between the factors analyzed and the presence of the metabolic 216 syndrome. In other words, our study, as in the Dutch group's study (Mulder et al., 2007; Mulder

217 et al., 2009; Risselada et al., 2012; Ma et al., 2014), only assessed the association between the

218 polymorphism studied and the metabolic syndrome; so to establish causality longitudinal studies

219 should be performed. We must point out that the sample of our patients corresponds to a

220 population treated with atypical antipsychotics, thus we cannot extrapolate the results to the

221 general population (high heterogeneity). However, the aim of this study was to analyze the

222 association between the metabolic syndrome and the polymorphism studied in patients with this

223 type of treatment. Consequently, the results were obtained from a homogeneous sample of the

224 population treated with atypical antipsychotics. Moreover, the development of the metabolic

225 syndrome may have affected which medication the patients were given. However, Tables 1-3

226 show that patients with treatment of an unfavorable metabolic profile had a very similar

227 proportion of the metabolic syndrome compared with the total sample. 


\section{Comparison with the existing literature}

231

232

233

234

235

236

237

238

239

240

241

242

243

244

245

246

247

248

249

250

Although several studies address the possible associations between different HTR2C gene polymorphisms and the presence of the metabolic syndrome, only the Dutch studies focus on the rs1414334 polymorphism (Mulder et al., 2007; Mulder et al., 2009; Risselada et al., 2012; Ma et al., 2014). The main statistically significant finding of these studies was a direct association between the presence of the $\mathrm{C}$ allele of the polymorphism and the metabolic syndrome. As our results differ from those of these other authors, we cannot consider the association to be confirmed. Furthermore, the Dutch group did not stratify their results by gender, and since the HTR2C gene is X-linked, gender-specific analyses should have been carried out.

In agreement with Kuzman et al. (Kuzman et al., 2008), it is possible that the variability of factors analyzed may influence the differences found. The prevalence of the $\mathrm{C}$ allele of the polymorphism analyzed in our study was similar to that of the Dutch studies. Conversely, the prevalence of the metabolic syndrome in our sample was slightly higher (Mulder et al., 2007; Mulder et al., 2009; Risselada et al., 2012; Ma et al., 2014). Additionally, previous studies did not assess atypical antipsychotics exclusively, as a percentage of the subjects had been prescribed traditional antipsychotics. Finally, the prevalence of schizophrenia in these papers was higher than in ours (Mulder et al., 2007; Mulder et al., 2009; Risselada et al., 2012). It is possible there were other differences on variables that were not reported in the Dutch studies. For example, our patients had their disease for an average of almost 15 years and had been taking the current antipsychotic medication for approximately five years. This information has not been analyzed by the Dutch group. On the other hand, there is a strong possibility that previous 
251 findings were false positives (Ioannidis et al., 2001). Therefore, the differences might be due to

252 these factors.

253

254 Implications for research

255 The set of studies by the Dutch group indicates that the presence of the C allele of the HTR2C

256 rs 1414334 gene polymorphism appears to be associated with the metabolic syndrome. Our

257 findings, however, do not support this association. As mentioned above, this could be due to

258 differences between our patients and those of the Dutch group or could indicate type 1 error in

259 the original findings. To distinguish these possibilities we would need multicentre studies

260 evaluating the association in different antipsychotic treatments, preferably using a prospective

261 design. However, before investing in such research, it would be helpful to establish whether this

262 SNP has a functional influence.

263

264 ACKNOWLEDGEMENTS

265 The authors thank Maria Repice and Ian Johnstone for help with the English language version of 266 the text. 
268

269

270

271

272

273

274

275

276

277

278

279

280

281

282

283

284

285

286

\section{REFERENCES}

Agencia Valenciana de Salud. 2011. Resolución de 13 de enero de 2010, resolución del Director Gerente de la Agencia Valenciana de Salud por el que se establecen nuevas condiciones en la prescripción, planificación y entrega de recetas médicas oficiales de la Conselleria de Sanitat.

Alberti KG, Zimmet P, Shaw J; IDF Epidemiology Task Force Consensus Group. 2005. The metabolic syndrome--a new worldwide definition. Lancet 366: 1059-1062.

American Diabetes Association. 2012. Standards of medical care in diabetes--2012. Diabetes

Care 35 Suppl 1: S11-63.

American Diabetes Association, American Psychiatric Association, American Association of Clinical Endocrinologists, North American Association for the Study of Obesity. 2004.

Consensus Development Conference on Antipsychotic Drugs and Obesity and Diabetes. Journal of Clinical Psychiatry 65: 267-272.

American Psychiatric Association. 2000. Diagnostic and Statistical Manual of Mental Disorders, Fourth Edition. Michigan: Amer Psychiatric Pub Incorporated. 
287 Bonhaus DW, Weinhardt KK, Taylor M, DeSouza A, McNeeley PM, Szczepanski K, Fontana

288 DJ, Trinh J, Rocha CL, Dawson MW, Flippin LA, Eglen RM. 1997. RS-102221: a novel high 289 affinity and selective, 5-HT2C receptor antagonist. Neuropharmacology 36:621-629.

Casey DE, Haupt DW, Newcomer JW, Henderson DC, Sernyak MJ, Davidson M, Lindenmayer JP, Manoukian SV, Banerji MA, Lebovitz HE, Hennekens CH. 2004. Antipsychotic-induced weight gain and metabolic abnormalities: implications for increased mortality in patients with schizophrenia. Journal of Clinical Psychiatry 65 Suppl 7: 4-18; quiz 19-20. Review.

Clifton PG, Lee MD, Dourish CT. 2000. Similarities in the action of Ro 60-0175, a 5-HT2C receptor agonist and d-fenfluramine on feeding patterns in the rat. Psychopharmacology 152:256-267. group. 2013. Metabolic risk factors in first-episode schizophrenia: baseline prevalence and course analysed from the European First-Episode Schizophrenia Trial. International Journal of Neuropsychopharmacology 16: 987-995. 
307 atypical antipsychotics: an extension of the monozygotic twin and sib pair study. Journal of

308 Clinical Pharmacy and Therapeutics 35:207-211.

309

310 Grundy SM, Brewer HB Jr, Cleeman JI, Smith SC Jr, Lenfant C; American Heart Association;

311 National Heart, Lung, and Blood Institute. 2004. Definition of metabolic syndrome: Report of

312 the National Heart, Lung, and Blood Institute/American Heart Association conference on

313 scientific issues related to definition. Circulation 109: 433-438. Review.

Ioannidis JP, Ntzani EE, Trikalinos TA, Contopoulos-Ioannidis DG. 2001. Replication validity of genetic association studies. Nature Genetics 29:306-309.

Kuzman MR, Medved V, Bozina N, Hotujac L, Sain I, Bilusic H. 2008. The influence of 5HT(2C) and MDR1 genetic polymorphisms on antipsychotic-induced weight gain in female schizophrenic patients. Psychiatry Research 160: 308-315.

McEvoy JP, Meyer JM, Goff DC, Nasrallah HA, Davis SM, Sullivan L, Meltzer HY, Hsiao J, 323 Scott Stroup T, Lieberman JA. 2005. Prevalence of the metabolic syndrome in patients with 324 schizophrenia: baseline results from the Clinical Antipsychotic Trials of Intervention 325 Effectiveness (CATIE) schizophrenia trial and comparison with national estimates from 326 NHANES III. Schizophrenia Research 80: 19-32. 
Ma X, Maimaitirexiati T, Zhang R, Gui X, Zhang W, Xu G, Hu G. 2014. HTR2C

polymorphisms, olanzapine-induced weight gain and antipsychotic-induced metabolic syndrome in schizophrenia patients: a meta-analysis. International Journal of Psychiatry in Clinical

331 Practice 18: 229-242.

Mancia G, De Backer G, Dominiczak A, Cifkova R, Fagard R, Germano G, Grassi G, Heagerty

Widimsky P, Zamorano JL, Erdine S, Kiowski W, Agabiti-Rosei E, Ambrosioni E, Lindholm

Erdine S, Farsang C, Gaita D, Lip G, Mallion JM, Manolis AJ, Nilsson PM, O'Brien E,

Ponikowski P, Redon J, Ruschitzka F, Tamargo J, van Zwieten P, Waeber B, Williams B;

Management of Arterial Hypertension of the European Society of Hypertension; European

Society of Cardiology. 2007. 2007 Guidelines for the Management of Arterial Hypertension: The

Task Force for the Management of Arterial Hypertension of the European Society of 25: 1105-1187. Erratum in: Journal Hypertension 25: 1749.

347 Meyer JM, Stahl SM. 2009. The metabolic syndrome and schizophrenia. Acta Psychiatrica 348 Scandinavica 119: 4-14. 
350 Ministerio de Sanidad, Servicios Sociales e Igualdad, Instituto Nacional de Estadística. 2011.

351 Encuesta Nacional de Salud 2011-2012. Available at

352 http://www.msssi.gob.es/estadEstudios/estadisticas/encuestaNacional/encuestaNac2011/Cuestio

353 nario Adultos.pdf (accessed March 2015).

Ministerio de Sanidad, Política Social e Igualdad, Instituto Nacional de Estadística. Encuesta

356 Europea de Salud 2009. 2009. Available at

357 http://www.ine.es/metodologia/t15/t153042009cues.pdf (accessed March 2015).

Mulder H, Cohen D, Scheffer H, Gispen-de Wied C, Arends J, Wilmink FW, Franke B, Egberts

AC. 2009. HTR2C gene polymorphisms and the metabolic syndrome in patients with schizophrenia: a replication study. Journal of Clinical Psychopharmacology 29: 16-20.

Mulder H, Franke B, van der-Beek van der AA, Arends J, Wilmink FW, Scheffer H, Egberts AC. 2007. The association between HTR2C gene polymorphisms and the metabolic syndrome in patients with schizophrenia. Journal of Clinical Psychopharmacology 27: 338-343.

367 National Cholesterol Education Program (NCEP) Expert Panel on Detection, Evaluation, and Treatment of High Blood Cholesterol in Adults (Adult Treatment Panel III). 2002. Third Report 
369 of the National Cholesterol Education Program (NCEP) Expert Panel on Detection, Evaluation,

370 and Treatment of High Blood Cholesterol in Adults (Adult Treatment Panel III) final report.

371 Circulation 106: 3143-3421.

372

373 Newcomer JW. 2004. Metabolic risk during antipsychotic treatment. Clinical Therapeutics 26:

374 1936-1946. Review.

375

376 No authors listed. 1998. Clinical Guidelines on the Identification, Evaluation, and Treatment of

377 Overweight and Obesity in Adults--The Evidence Report. National Institutes of Health. Obesity

378 Research 6 Suppl 2: 51S-209S. Review.

Osby U, Correia N, Brandt L, Ekbom A, Sparén P. 2000. Mortality and causes of death in schizophrenia in Stockholm county, Sweden. Schizophrenia Research 45: 21-28.

Ramírez-Prado D, Palazón-Bru A, Folgado-de-la Rosa DM, Carbonell-Torregrosa MA, Martínez-Díaz AM, Gil-Guillén VF. 2015. Predictive models for all-cause and cardiovascular mortality in type 2 diabetic inpatients. A cohort study. International Journal of Clinical Practice 386 69: 474-484. 
388 Reynolds GP, Hill MJ, Kirk SL. 2006. The 5-HT2C receptor and antipsychotic induced weight 389 gain - mechanisms and genetics. Journal of Psychopharmacology 20(4 Suppl):15-18. Review.

390

391

392

393

394

395

396

397

398

399

400

401

402

403

404

405

406

Risselada AJ, Vehof J, Bruggeman R, Wilffert B, Cohen D, Al Hadithy AF, Arends J, Mulder H. 2012. Association between HTR2C gene polymorphisms and the metabolic syndrome in patients using antipsychotics: a replication study. Pharmacogenomics $J$ 12: 62-67.

Schreiner A, Niehaus D, Shuriquie NA, Aadamsoo K, Korcsog P, Salinas R, Theodoropoulou P, Fernández LG, Uçok A, Tessier C, Bergmans P, Hoeben D. 2012. Metabolic effects of paliperidone extended release versus oral olanzapine in patients with schizophrenia: a prospective, randomized, controlled trial. Journal of Clinical Psychopharmacology 32: 449-457. Erratum in: Journal of Clinical Psychopharmacology 32: 803.

Stahl SM, Mignon L, Meyer JM. 2009. Which comes first: atypical antipsychotic treatment or cardiometabolic risk? Acta Psychiatrica Scandinavica 119: 171-179. Review.

Stoner SC, Pace HA. 2012. Asenapine: a clinical review of a second-generation antipsychotic. Clinical Therapeutics 34: 1023-1040. 
407 von Meyenburg C, Langhans W, Hrupka BJ. 2003. Evidence for a role of the 5-HT2C receptor in

408 central lipopolysaccharide-, interleukin-1 beta-, and leptin-induced anorexia. Pharmacology

409 Biochemistry and Behavior 74:1025-1031.

410

411 Wallace TJ, Zai CC, Brandl EJ, Müller DJ. 2011. Role of 5-HT(2C) receptor gene variants in

412 antipsychotic-induced weight gain. Pharmacogenomics and Personalized Medicine 4: 83-93.

413

414 World Health Organization. 2014. The top 10 causes of death. Available at

415 http://www.who.int/mediacentre/factsheets/fs310/en/(accessed March 2015).

416

417 Young SL, Taylor M, Lawrie SM. 2015. "First do no harm." A systematic review of the

418 prevalence and management of antipsychotic adverse effects. Journal of Psychopharmacology

419 29: 353-362. Review.

420 


\section{Table $\mathbf{1}$ (on next page)}

Factors associated with metabolic syndrome in the patients diagnosed with psychiatric disorders in a Spanish region: total sample.

Abbreviations: Adj. OR, adjusted odds ratio; $\mathrm{Cl}$, confidence interval; $\mathrm{MS}$, metabolic syndrome; $\mathrm{N} / \mathrm{M}$, not in the model; $\mathrm{n}(\%)$, absolute frequency (relative frequency); $\mathrm{x} \pm \mathrm{s}$, mean \pm standard deviation. Goodness-of-fit of the multivariate model: $X^{2}=16.96, p=0.009$. Regular physical activity was assessed on a scale as follows: 0, sitting; 1 standing; 2 walking or moving around; 3 great effort. Physical activity during leisure time was measured using the following scale: 0 , never; 1 , less than once per month; 2 once or several times per month; 3 , one or more times per week. The scale of all the food was rated as: 0 , daily; 1 , three or more times a week; 2, once or twice a week; 3, less than once a week; 4 never or almost never. 


\begin{tabular}{|c|c|c|c|c|c|}
\hline Variable & $\begin{array}{c}\text { Total } \\
\mathrm{n}=166 \\
\mathrm{n}(\%) / \mathrm{x} \pm \mathrm{s} \\
\end{array}$ & $\begin{array}{c}\text { With MS } \\
\mathrm{n}=68(41.0 \%) \\
\mathrm{n}(\%) / \mathrm{x} \pm \mathrm{S}\end{array}$ & p-value & $\begin{array}{l}\text { Adj. OR } \\
(95 \% \text { CI })\end{array}$ & p-value \\
\hline $\begin{array}{l}\text { rs1414334 allele: } \\
\text { C } \\
\text { G }\end{array}$ & $\begin{array}{c}33(19.9) \\
133(80.1)\end{array}$ & $\begin{array}{l}10(30.3) \\
58(43.6)\end{array}$ & 0.164 & $\begin{array}{c}0.42(0.17-1.04) \\
1\end{array}$ & 0.062 \\
\hline $\begin{array}{l}\text { Gender: } \\
\text { Male } \\
\text { Female }\end{array}$ & $\begin{array}{l}99(59.6) \\
67(40.4)\end{array}$ & $\begin{array}{l}45(45.5) \\
23(34.3)\end{array}$ & 0.153 & $\mathrm{~N} / \mathrm{M}$ & $\mathrm{N} / \mathrm{M}$ \\
\hline Age (years) & $43.1 \pm 11.5$ & $45.3 \pm 11.0$ & 0.038 & $1.03(0.99-1.06)$ & 0.158 \\
\hline $\begin{array}{l}\text { Schizophrenia: } \\
\text { Yes } \\
\text { No }\end{array}$ & $\begin{array}{l}92(55.4) \\
74(44.6)\end{array}$ & $\begin{array}{l}41(44.6) \\
27(36.5)\end{array}$ & 0.293 & $\mathrm{~N} / \mathrm{M}$ & $\mathrm{N} / \mathrm{M}$ \\
\hline Years with the disorder & $14.9 \pm 9.6$ & $16.4 \pm 9.0$ & 0.099 & $1.01(0.97-1.05)$ & 0.654 \\
\hline Years with the current therapy & $5.3 \pm 4.5$ & $5.0 \pm 4.7$ & 0.594 & $\mathrm{~N} / \mathrm{M}$ & $\mathrm{N} / \mathrm{M}$ \\
\hline $\begin{array}{l}\text { Therapy with a favorable metabolic profile: } \\
\text { Yes } \\
\text { No }\end{array}$ & $\begin{array}{c}49(29.5) \\
117(70.5)\end{array}$ & $\begin{array}{l}19(38.8) \\
49(41.9)\end{array}$ & 0.711 & $\mathrm{~N} / \mathrm{M}$ & $\mathrm{N} / \mathrm{M}$ \\
\hline $\begin{array}{l}\text { Therapy with an unfavorable metabolic profile: } \\
\text { Yes } \\
\text { No }\end{array}$ & $\begin{array}{c}137(82.5) \\
29(17.5)\end{array}$ & $\begin{array}{l}56(40.9) \\
12(41.4) \\
\end{array}$ & 0.960 & $\mathrm{~N} / \mathrm{M}$ & $\mathrm{N} / \mathrm{M}$ \\
\hline $\begin{array}{l}\text { Antidepressants: } \\
\text { Yes } \\
\text { No }\end{array}$ & $\begin{array}{c}47(28.3) \\
119(71.7) \\
\end{array}$ & $\begin{array}{l}25(53.2) \\
43(36.1)\end{array}$ & 0.044 & $\begin{array}{c}2.12(1.00-4.49) \\
1 \\
\end{array}$ & 0.051 \\
\hline $\begin{array}{l}\text { Mood stabilizers: } \\
\text { Yes } \\
\text { No }\end{array}$ & $\begin{array}{l}37(22.3) \\
37(22.3)\end{array}$ & $\begin{array}{l}17(45.9) \\
51(39.5)\end{array}$ & 0.485 & $\mathrm{~N} / \mathrm{M}$ & $\mathrm{N} / \mathrm{M}$ \\
\hline Number of pack-years & $11.6 \pm 17.5$ & $14.8 \pm 22.3$ & 0.073 & $1.02(1.00-1.04)$ & 0.055 \\
\hline Sleeping hours & $8.9 \pm 1.9$ & $8.9 \pm 1.9$ & 0.841 & $\mathrm{~N} / \mathrm{M}$ & $\mathrm{N} / \mathrm{M}$ \\
\hline Physical activity at work and home & $0.9 \pm 0.8$ & $0.8 \pm 0.8$ & 0.116 & $0.80(0.52-1.21)$ & 0.286 \\
\hline Physical activity in leisure time & $1.1 \pm 1.2$ & $1.0 \pm 1.2$ & 0.222 & $\mathrm{~N} / \mathrm{M}$ & $\mathrm{N} / \mathrm{M}$ \\
\hline Fruit & $1.1 \pm 1.2$ & $1.2 \pm 1.3$ & 0.469 & $\mathrm{~N} / \mathrm{M}$ & $\mathrm{N} / \mathrm{M}$ \\
\hline Meat & $1.1 \pm 0.9$ & $1.0 \pm 0.8$ & 0.203 & $\mathrm{~N} / \mathrm{M}$ & $\mathrm{N} / \mathrm{M}$ \\
\hline Eggs & $1.8 \pm 0.8$ & $1.7 \pm 0.8$ & 0.336 & $\mathrm{~N} / \mathrm{M}$ & $\mathrm{N} / \mathrm{M}$ \\
\hline Fish & $2.0 \pm 0.9$ & $2.0 \pm 0.9$ & 0.398 & $\mathrm{~N} / \mathrm{M}$ & $\mathrm{N} / \mathrm{M}$ \\
\hline Pasta, rice and potatoes & $1.1 \pm 0.9$ & $1.1 \pm 0.9$ & 0.714 & $\mathrm{~N} / \mathrm{M}$ & $\mathrm{N} / \mathrm{M}$ \\
\hline Bread and cereals & $0.5 \pm 0.9$ & $0.4 \pm 0.9$ & 0.294 & $\mathrm{~N} / \mathrm{M}$ & $\mathrm{N} / \mathrm{M}$ \\
\hline Vegetables & $1.1 \pm 1.2$ & $1.3 \pm 1.2$ & 0.137 & $\mathrm{~N} / \mathrm{M}$ & $\mathrm{N} / \mathrm{M}$ \\
\hline Legumes & $1.8 \pm 0.9$ & $1.8 \pm 1.0$ & 0.643 & $\mathrm{~N} / \mathrm{M}$ & $\mathrm{N} / \mathrm{M}$ \\
\hline Cold meats & $2.1 \pm 1.3$ & $2.0 \pm 1.3$ & 0.539 & $\mathrm{~N} / \mathrm{M}$ & $\mathrm{N} / \mathrm{M}$ \\
\hline Milk products & $0.7 \pm 1.0$ & $0.6 \pm 1.0$ & 0.622 & $\mathrm{~N} / \mathrm{M}$ & $\mathrm{N} / \mathrm{M}$ \\
\hline Sweets & $2.1 \pm 1.4$ & $2.1 \pm 1.4$ & 0.913 & $\mathrm{~N} / \mathrm{M}$ & $\mathrm{N} / \mathrm{M}$ \\
\hline
\end{tabular}




\section{Table 2 (on next page)}

Factors associated with metabolic syndrome in the patients diagnosed with psychiatric disorders in a Spanish region: males.

Abbreviations: Adj. OR, adjusted odds ratio; $\mathrm{Cl}$, confidence interval; $\mathrm{MS}$, metabolic syndrome; $\mathrm{N} / \mathrm{M}$, not in the model; $\mathrm{n}(\%)$, absolute frequency (relative frequency); $x \pm s$, mean \pm standard deviation. Goodness-of-fit of the multivariate model: $X^{2}=10.96, p=0.027$. Regular physical activity was assessed on a scale as follows: 0, sitting; 1 standing; 2 walking or moving around; 3 great effort. Physical activity during leisure time was measured using the following scale: 0 , never; 1 , less than once per month; 2 once or several times per month; 3 , one or more times per week. The scale of all the food was rated as: 0 , daily; 1 , three or more times a week; 2, once or twice a week; 3, less than once a week; 4 never or almost never. 


\begin{tabular}{|c|c|c|c|c|c|}
\hline Variable & $\begin{array}{c}\text { Total } \\
\mathrm{n}=99 \\
\mathrm{n}(\%) / \mathrm{x} \pm \mathrm{s}\end{array}$ & $\begin{array}{c}\text { With MS } \\
\mathrm{n}=45(45.5 \%) \\
\mathrm{n}(\%) / \mathrm{x} \pm \mathrm{s}\end{array}$ & p-value & $\begin{array}{l}\text { Adj. OR } \\
(95 \% \mathrm{CI})\end{array}$ & $\mathrm{p}$-value \\
\hline $\begin{array}{l}\text { rs1414334 allele: } \\
\text { C } \\
\text { G }\end{array}$ & $\begin{array}{l}14(14.1) \\
85(85.9)\end{array}$ & $\begin{array}{c}5(35.7) \\
40(47.1) \\
\end{array}$ & 0.430 & $\begin{array}{c}0.35(0.09-1.42) \\
1\end{array}$ & 0.141 \\
\hline Age (years) & $39.9 \pm 8.9$ & $42.4 \pm 8.8$ & 0.011 & $1.06(1.00-1.12)$ & 0.036 \\
\hline $\begin{array}{l}\text { Schizophrenia: } \\
\text { Yes } \\
\text { No }\end{array}$ & $\begin{array}{l}62(62.6) \\
37(37.4) \\
\end{array}$ & $\begin{array}{l}30(48.4) \\
15(40.5)\end{array}$ & 0.448 & $\mathrm{~N} / \mathrm{M}$ & $\mathrm{N} / \mathrm{M}$ \\
\hline Years with the disorder & $14.5 \pm 8.0$ & $15.8 \pm 7.9$ & 0.166 & $\mathrm{~N} / \mathrm{M}$ & $\mathrm{N} / \mathrm{M}$ \\
\hline Years with the current therapy & $5.4 \pm 4.6$ & $5.2 \pm 4.9$ & 0.635 & $\mathrm{~N} / \mathrm{M}$ & $\mathrm{N} / \mathrm{M}$ \\
\hline $\begin{array}{l}\text { Therapy with a favorable metabolic profile: } \\
\text { Yes } \\
\text { No }\end{array}$ & $\begin{array}{l}27(27.3) \\
72(72.7) \\
\end{array}$ & $\begin{array}{l}11(40.7) \\
34(47.2) \\
\end{array}$ & 0.564 & $\mathrm{~N} / \mathrm{M}$ & $\mathrm{N} / \mathrm{M}$ \\
\hline $\begin{array}{l}\text { Therapy with an unfavorable metabolic profile: } \\
\text { Yes } \\
\text { No }\end{array}$ & $\begin{array}{l}83(83.8) \\
16(16.2)\end{array}$ & $\begin{array}{c}39(47.0) \\
6(37.5)\end{array}$ & 0.485 & $\mathrm{~N} / \mathrm{M}$ & $\mathrm{N} / \mathrm{M}$ \\
\hline $\begin{array}{l}\text { Antidepressants: } \\
\text { Yes } \\
\text { No }\end{array}$ & $\begin{array}{l}22(22.2) \\
77(77.8) \\
\end{array}$ & $\begin{array}{l}13(59.1) \\
32(41.6) \\
\end{array}$ & 0.145 & $\mathrm{~N} / \mathrm{M}$ & $\mathrm{N} / \mathrm{M}$ \\
\hline $\begin{array}{l}\text { Mood stabilizers: } \\
\text { Yes } \\
\text { No }\end{array}$ & $\begin{array}{l}25(25.3) \\
74(74.7)\end{array}$ & $\begin{array}{l}15(60.0) \\
30(40.5)\end{array}$ & 0.091 & $\begin{array}{c}2.16(0.79-5.91) \\
1\end{array}$ & 0.134 \\
\hline Number of pack-years & $13.9 \pm 19.9$ & $17.6 \pm 25.3$ & 0.119 & $1.01(0.99-1.04)$ & 0.418 \\
\hline Sleeping hours & $8.9 \pm 2.1$ & $8.7 \pm 2.1$ & 0.432 & $\mathrm{~N} / \mathrm{M}$ & $\mathrm{N} / \mathrm{M}$ \\
\hline Physical activity at work and home & $0.9 \pm 0.9$ & $0.8 \pm 0.8$ & 0.140 & $\mathrm{~N} / \mathrm{M}$ & $\mathrm{N} / \mathrm{M}$ \\
\hline Physical activity in leisure time & $1.1 \pm 1.2$ & $1.0 \pm 1.2$ & 0.483 & $\mathrm{~N} / \mathrm{M}$ & $\mathrm{N} / \mathrm{M}$ \\
\hline Fruit & $1.3 \pm 1.2$ & $1.4 \pm 1.3$ & 0.231 & $\mathrm{~N} / \mathrm{M}$ & $\mathrm{N} / \mathrm{M}$ \\
\hline Meat & $1.0 \pm 0.8$ & $0.9 \pm 0.7$ & 0.488 & $\mathrm{~N} / \mathrm{M}$ & $\mathrm{N} / \mathrm{M}$ \\
\hline Eggs & $1.7 \pm 0.9$ & $1.5 \pm 0.9$ & 0.122 & $\mathrm{~N} / \mathrm{M}$ & $\mathrm{N} / \mathrm{M}$ \\
\hline Fish & $2.0 \pm 0.9$ & $2.1 \pm 1.0$ & 0.451 & $\mathrm{~N} / \mathrm{M}$ & $\mathrm{N} / \mathrm{M}$ \\
\hline Pasta, rice and potatoes & $1.1 \pm 0.9$ & $1.1 \pm 0.9$ & 0.685 & $\mathrm{~N} / \mathrm{M}$ & $\mathrm{N} / \mathrm{M}$ \\
\hline Bread and cereals & $0.4 \pm 0.8$ & $0.3 \pm 0.8$ & 0.287 & $\mathrm{~N} / \mathrm{M}$ & $\mathrm{N} / \mathrm{M}$ \\
\hline Vegetables & $1.4 \pm 1.2$ & $1.5 \pm 1.2$ & 0.374 & $\mathrm{~N} / \mathrm{M}$ & $\mathrm{N} / \mathrm{M}$ \\
\hline Legumes & $1.9 \pm 0.9$ & $1.9 \pm 1.0$ & 0.448 & $\mathrm{~N} / \mathrm{M}$ & $\mathrm{N} / \mathrm{M}$ \\
\hline Cold meats & $2.0 \pm 1.2$ & $1.9 \pm 1.3$ & 0.636 & $\mathrm{~N} / \mathrm{M}$ & $\mathrm{N} / \mathrm{M}$ \\
\hline Milk products & $0.7 \pm 1.0$ & $0.7 \pm 1.0$ & 0.805 & $\mathrm{~N} / \mathrm{M}$ & $\mathrm{N} / \mathrm{M}$ \\
\hline Sweets & $2.0 \pm 1.4$ & $1.9 \pm 1.4$ & 0.553 & $\mathrm{~N} / \mathrm{M}$ & $\mathrm{N} / \mathrm{M}$ \\
\hline
\end{tabular}




\section{Table 3 (on next page)}

Factors associated with metabolic syndrome in the patients diagnosed with psychiatric disorders in a Spanish region: females.

Abbreviations: Adj. OR, adjusted odds ratio; $\mathrm{Cl}$, confidence interval; $\mathrm{MS}$, metabolic syndrome; $\mathrm{N} / \mathrm{M}$, not in the model; $\mathrm{n}(\%)$, absolute frequency (relative frequency); $x \pm s$, mean \pm standard deviation. Goodness-of-fit of the multivariate model: $X^{2}=4.31, p=0.116$. Regular physical activity was assessed on a scale as follows: 0, sitting; 1 standing; 2 walking or moving around; 3 great effort. Physical activity during leisure time was measured using the following scale: 0 , never; 1 , less than once per month; 2 once or several times per month; 3 , one or more times per week. The scale of all the food was rated as: 0 , daily; 1 , three or more times a week; 2, once or twice a week; 3, less than once a week; 4 never or almost never. 


\begin{tabular}{|c|c|c|c|c|c|}
\hline Variable & $\begin{array}{c}\text { Total } \\
\mathrm{n}=67 \\
\mathrm{n}(\%) / \mathrm{x} \pm \mathrm{s}\end{array}$ & $\begin{array}{c}\text { With MS } \\
\mathrm{n}=23(35.4 \%) \\
\mathrm{n}(\%) / \mathrm{x} \pm \mathrm{s}\end{array}$ & $\mathrm{p}$-value & $\begin{array}{c}\text { Adj. OR } \\
(95 \% \mathrm{CI})\end{array}$ & $\mathrm{p}$-value \\
\hline $\begin{array}{l}\text { rs1414334 allele: } \\
\text { C } \\
\text { G }\end{array}$ & $\begin{array}{l}19(28.4) \\
48(71.6)\end{array}$ & $\begin{array}{c}5(26.3) \\
18(37.5)\end{array}$ & 0.385 & $\begin{array}{c}0.54(0.16-1.82) \\
1\end{array}$ & 0.318 \\
\hline Age (years) & $47.7 \pm 13.3$ & $51.0 \pm 12.8$ & 0.148 & $\mathrm{~N} / \mathrm{M}$ & $\mathrm{N} / \mathrm{M}$ \\
\hline $\begin{array}{l}\text { Schizophrenia: } \\
\text { Yes } \\
\text { No }\end{array}$ & $\begin{array}{l}30(44.8) \\
37(55.2)\end{array}$ & $\begin{array}{l}11(36.7) \\
12(32.4)\end{array}$ & 0.717 & $\mathrm{~N} / \mathrm{M}$ & $\mathrm{N} / \mathrm{M}$ \\
\hline Years with the disorder & $15.4 \pm 11.6$ & $17.6 \pm 10.9$ & 0.269 & $\mathrm{~N} / \mathrm{M}$ & $\mathrm{N} / \mathrm{M}$ \\
\hline Years with the current therapy & $5.1 \pm 4.3$ & $4.8 \pm 4.4$ & 0.735 & $\mathrm{~N} / \mathrm{M}$ & $\mathrm{N} / \mathrm{M}$ \\
\hline $\begin{array}{l}\text { Therapy with a favorable metabolic profile: } \\
\text { Yes } \\
\text { No }\end{array}$ & $\begin{array}{l}22(32.8) \\
45(67.2) \\
\end{array}$ & $\begin{array}{c}8(36.4) \\
15(33.3) \\
\end{array}$ & 0.806 & $\mathrm{~N} / \mathrm{M}$ & $\mathrm{N} / \mathrm{M}$ \\
\hline $\begin{array}{l}\text { Therapy with an unfavorable metabolic profile: } \\
\text { Yes } \\
\text { No }\end{array}$ & $\begin{array}{l}54(80.6) \\
13(19.4)\end{array}$ & $\begin{array}{c}17(31.5) \\
6(46.2)\end{array}$ & 0.344 & $\mathrm{~N} / \mathrm{M}$ & $\mathrm{N} / \mathrm{M}$ \\
\hline $\begin{array}{l}\text { Antidepressants: } \\
\text { Yes } \\
\text { No }\end{array}$ & $\begin{array}{l}25(37.3) \\
42(62.7) \\
\end{array}$ & $\begin{array}{l}12(48.0) \\
11(26.2)\end{array}$ & 0.069 & $\begin{array}{c}2.74(0.95-7.90) \\
1 \\
\end{array}$ & 0.063 \\
\hline $\begin{array}{l}\text { Mood stabilizers: } \\
\text { Yes } \\
\text { No }\end{array}$ & $\begin{array}{l}12(17.9) \\
55(82.1)\end{array}$ & $\begin{array}{c}2(16.7) \\
21(38.2)\end{array}$ & 0.195 & $\mathrm{~N} / \mathrm{M}$ & $\mathrm{N} / \mathrm{M}$ \\
\hline Number of pack-years & $8.2 \pm 12.6$ & $9.6 \pm 14.3$ & 0.517 & $\mathrm{~N} / \mathrm{M}$ & $\mathrm{N} / \mathrm{M}$ \\
\hline Sleeping hours & $8.9 \pm 1.6$ & $9.2 \pm 1.5$ & 0.348 & $\mathrm{~N} / \mathrm{M}$ & $\mathrm{N} / \mathrm{M}$ \\
\hline Physical activity at work and home & $1.0 \pm 0.8$ & $1.0 \pm 0.8$ & 0.648 & $\mathrm{~N} / \mathrm{M}$ & $\mathrm{N} / \mathrm{M}$ \\
\hline Physical activity in leisure time & $1.1 \pm 1.1$ & $0.9 \pm 1.1$ & 0.261 & $\mathrm{~N} / \mathrm{M}$ & $\mathrm{N} / \mathrm{M}$ \\
\hline Fruit & $0.9 \pm 1.1$ & $0.9 \pm 1.2$ & 0.732 & $\mathrm{~N} / \mathrm{M}$ & $\mathrm{N} / \mathrm{M}$ \\
\hline Meat & $1.2 \pm 1.0$ & $1.2 \pm 0.9$ & 0.958 & $\mathrm{~N} / \mathrm{M}$ & $\mathrm{N} / \mathrm{M}$ \\
\hline Eggs & $1.9 \pm 0.8$ & $2.0 \pm 0.7$ & 0.419 & $\mathrm{~N} / \mathrm{M}$ & $\mathrm{N} / \mathrm{M}$ \\
\hline Fish & $2.0 \pm 0.8$ & $2.0 \pm 0.7$ & 0.733 & $\mathrm{~N} / \mathrm{M}$ & $\mathrm{N} / \mathrm{M}$ \\
\hline Pasta, rice and potatoes & $1.2 \pm 0.9$ & $1.0 \pm 0.9$ & 0.363 & $\mathrm{~N} / \mathrm{M}$ & $\mathrm{N} / \mathrm{M}$ \\
\hline Bread and cereals & $0.7 \pm 1.1$ & $0.6 \pm 1.1$ & 0.834 & $\mathrm{~N} / \mathrm{M}$ & $\mathrm{N} / \mathrm{M}$ \\
\hline Vegetables & $0.7 \pm 1.0$ & $0.9 \pm 1.1$ & 0.454 & $\mathrm{~N} / \mathrm{M}$ & $\mathrm{N} / \mathrm{M}$ \\
\hline Legumes & $1.7 \pm 0.9$ & $1.6 \pm 0.8$ & 0.647 & $\mathrm{~N} / \mathrm{M}$ & $\mathrm{N} / \mathrm{M}$ \\
\hline Cold meats & $2.3 \pm 1.4$ & $2.3 \pm 1.4$ & 0.891 & $\mathrm{~N} / \mathrm{M}$ & $\mathrm{N} / \mathrm{M}$ \\
\hline Milk products & $0.7 \pm 1.1$ & $0.6 \pm 1.1$ & 0.617 & $\mathrm{~N} / \mathrm{M}$ & $\mathrm{N} / \mathrm{M}$ \\
\hline Sweets & $2.2 \pm 1.5$ & $2.4 \pm 1.4$ & 0.493 & $\mathrm{~N} / \mathrm{M}$ & N/M \\
\hline
\end{tabular}

